\title{
Seasonal Variation in the Content of Condensed Tannins in Leaves of Xylopia emarginata Mart. (Annonaceae) in Response to Phenology and Climate
}

\author{
Patrícia Conceição Medeiros ${ }^{1,2}$, Yule Roberta Ferreira Nunes ${ }^{1,3}$, Juliana Pimenta Cruz ${ }^{3}$, \\ Dayse Marcielle de Souza ${ }^{3}$, Marly Antonielle Ávila ${ }^{3}$, Franciellen Morais-Costa ${ }^{3}$, Sônia Ribeiro Arrudas ${ }^{3}$, \\ Viviane de Oliveira Vasconcelos ${ }^{4}$, Thallyta Maria Vieira ${ }^{3}$ \& Ana Paula Venuto Moura ${ }^{1,3}$ \\ ${ }^{1}$ Programa de Pós-graduação em Biotecnologia, Universidade Estadual de Montes Claros, MG, Brazil \\ ${ }^{2}$ Instituto Federal do Norte de Minas Gerais, Januária, MG, Brazil \\ ${ }^{3}$ Departamento de Biologia Geral, Universidade Estadual de Montes Claros, MG, Brazil \\ ${ }^{4}$ Departamento de Fisiopatologia, Universidade Estadual de Montes Claros, MG, Brazil \\ Correspondence: Ana Paula Venuto Moura, Departamento de Biologia Geral, Universidade Estadual de Montes \\ Claros, MG, Brazil. E-mail: ana.venuto@unimontes.br
}

Received: August 3, 2021

doi:10.5539/jas.v13n10p142
Accepted: September 2, 2021

Online Published: September 15, 2021

URL: https://doi.org/10.5539/jas.v13n10p142

\begin{abstract}
Variations in the concentrations of plant secondary metabolites can occur due to the phenological stages of the plants, combined with environmental variations. Plants rich in tannins are used in folk medicine for different purposes. Xylopia emarginata Mart. (Anonaceae)-"Pindaíba" has been used to treat skin edema, bronchitis and malaria. We evaluated variations in condensed tannin (CTs) contents in relation to phenological variables in leaves of Xylopia emarginata during one year. The study took place in a Vereda in northern Minas Gerais State, Brazil. Monthly phenological observations as well as quantifications of the contents of condensed leaf tannins in ethanol and aqueous extracts were performed. The production of $X$. emarginata leaves occurred throughout the study, with greater budding and leaf fall in the dry season. Phenological observations were correlated with CT levels and climatic data of precipitation and temperature. There was a significant correlation $(p<0.05)$ between fruiting and CT levels in the extracts, which were higher during the dry season, $13.2 \%$ in the ethanol extract and $7.8 \%$ in the aqueous extract.
\end{abstract}

Keywords: seasonality, proanthocyanidin, palm swamps, savanna, phenophases, plant extracts.

\section{Introduction}

Phenology can be defined as the study of the occurrence of vegetative and reproductive events of a species (Lieth, 1974), being an indicator of the ecosystem's response to climate change (Andrew et al., 2013, Abernethy et al., 2018). The influence of seasonality for plant growth and performance has been the subject of research to elucidate how phenology responds to environmental factors (Chuine \& Regniere, 2017).

The phenological stages of plants, combined with environmental variables, can modulate the biosynthesis of secondary compounds (Castro-Moreno et al., 2013). Studies indicate that substance concentrations are influenced by plant phenological stages and environmental factors such as precipitation and temperature (Pirbalouti et al., 2013; Djerrad et al., 2015; Pretti et al., 2018). The ecological implications that contribute to changes in the production levels of secondary metabolites are numerous and poorly understood (Schweitzer et al., 2008). Existing data indicate that climatic differences in precipitation and temperature are directly related to the phenological cycles of plants, and alter the levels of production of secondary metabolites (Simón, 1999; Ma et al., 2003).

Phenolic compounds are the most abundant secondary metabolites in plants, and receive more attention because of their distinct bioactivities (Alu'datt, 2017). The compounds of secondary plant metabolism have considerable value in the interactions between the plant and its ecosystem (Sant'ana \& Assad, 2002). The accumulation of these compounds varies over the seasons and depends on genetic and environmental factors (Fratianni et al., 
2007). These compounds have a common chemical structure that comprise an aromatic ring with one or more hydroxy substituents, whose main groups include flavonoids, phenolic acids, and tannins (Alu'datt, 2017).

Tannins are substances identified as plant defensive compounds (Zucker, 1983) exposed to environmental stresses such as drought (Getachew, 1999), found in several species of the Cerrado-Brazilian savanna (Morais-Costa et al., 2015) and have economic and ecological relevance (Monteiro et al., 2005). Due to their functional properties, added to the potential to add value and conserve the biodiversity of the Cerrado, the species of this biome have aroused growing interest (Rocha et al., 2011).

Plants of the genus Xylopia (160 species) have also stimulated interest in the search for the synthesis of new bioactive compounds, due to the numerous secondary compounds present and their respective bioactivities (Silva et al., 2015). The genus Xylopia is known as an antidiuretic in Brazilian popular medicine, and is used in the treatment of skin edema, and bronchitis (Macedo \& Ferreira, 2004; Nascimento et al., 2006), in the treatment of malaria and other infectious diseases (Mesquita et al., 2007), and in the isolation of larvicidal compounds against Aedes aegypti (Sousa et al., 2020). Xylopia emarginata extracts show antiplasmodic activity against malaria and other infectious diseases (Fischer et al., 2004; Mesquita et al., 2007), and larvicidal action against Aedes aegypti (Sousa et al., 2020). Ethanol extracts of Xylopia emarginata leaves having different tannin contents were also evaluated in in vitro tests against ticks, with high activities being observed that were related to tannin contents (Cruz et al., 2021).

Among the species of this genus, Xylopia emarginata Mart. (Annonaceae) stands out; "pindaíba" or "pindaíba do brejo", is a tree species native to Brazil, occurring from the state of Bahia to São Paulo (Lorenzi, 1992). It is typical of riparian or gallery forests, showing wide dispersion in the Cerrado biome in humid environments, such as Veredas - palm swamps and swamp forest (Lorenzi, 1992; Nunes et al., 2015). It is a medium-sized evergreen tree, 10 to $20 \mathrm{~m}$ tall and has a trunk 30 to $40 \mathrm{~cm}$ in diameter (Lorenzi, 1992). Xylopia emarginata has also been the subject of studies, in which terpenoids, flavonoids, and alkaloids were isolated from leaves (Moreira et al., 2003) and fruits (Moreira et al., 2006).

Few studies have verified the accumulation of low polarity metabolites for X. emarginata (Moreira et al., 2007) and the influence of environmental variables on the production of phenolic compounds (Castro-Moreno et al., 2013). Thus, this study aimed to evaluate the phenological behavior and the variation of the condensed tannin (CT) content of the aqueous and ethanolic extracts of the leaves of X. emarginata over a year, in a Vereda in northern Minas Gerais, Brazil.

\section{Materials and Methods}

\subsection{Study Area}

The survey was carried out in a Vereda vegetation (phytophysiognomie of Cerrado), called Vereda Almescla, in the municipality of Bonito de Minas, in the north of the state of Minas Gerais, Brazil $\left(44^{\circ} 53^{\prime} 46.5^{\prime \prime} \mathrm{W}\right.$ and $15^{\circ} 20^{\prime} 54.8^{\prime \prime} \mathrm{S}$ ). According to the Köppen classification, the predominant type of climate in the region is Aw (savanna climate), which is characterized by two well-defined seasons, dry and rainy (Alvares et al., 2013). To characterize the region's climatic norms, total precipitation and average temperature over the last 30 years (1989-2018) were considered. The rainy season runs from November to March and the dry season runs from April to October (Figure 1). 


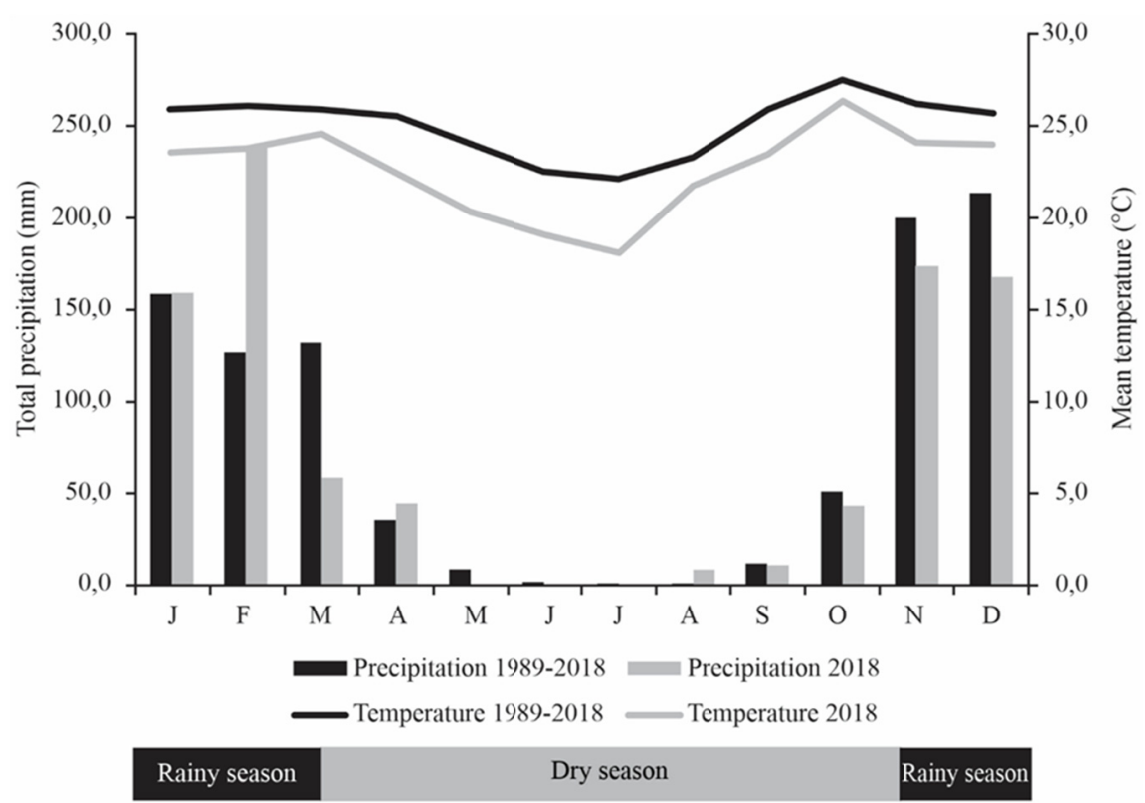

Figure 1. Climatic norms of total precipitation and mean temperature for the years 1989-2018, obtained from a climate station at Januária (Minas Gerais, Brazil) and total precipitation and mean temperature of the year 2018 obtained from a climate station in loco (Vereda Almescla, Bonito de Minas, Minas Gerais, Brazil)

Monthly data on total precipitation and average temperatures were collected from a weather station (Davis Vantage Pro $2^{\mathrm{TM}}$ Integrated Sensor Suite) present at the study site from February 2018 to January 2019. The highest precipitation rate was recorded in February $2018(240.6 \mathrm{~mm})$, and the lowest was observed in July 2018 $(0.2 \mathrm{~mm})$. The highest average temperature was observed in October $2018\left(26.5^{\circ} \mathrm{C}\right)$ and the lowest recorded in July $2018\left(18.2^{\circ} \mathrm{C}\right)$.

\subsection{Phenological Monitoring}

Thirty arboreal specimens of $X$. emarginata were selected, marked with numbered aluminum plates and zebra-streaked tape and monitored monthly, for 12 months (February/2018 to January/2019). The following vegetative phenophases were observed: (1) budding, marked by the emergence of new leaves; (2) mature leaves, represented by the presence of fully expanded leaves and the normal size and color of the species; and (3) leaf fall, characterized by leaf fall with ease of falling in the wind and leaves fallen under the treetops; and the reproductive phenophases: (4) flowering, characterized from the beginning of the flower formation to the fall of the floral parts; and (5) fruiting, characterized by the beginning of the fruit formation until the presence of ripe fruits, with a red color (modified from Nunes et al., 2005).

\subsection{Sample Collection and Aqueous and Ethanolic Extracts}

Leaves from 10 specimens of $X$. emarginata, followed during phenological monitoring, were collected and selected, discarding those that were deteriorated and/or damaged. The leaves were subsequently dehydrated in an oven with forced air circulation at $40^{\circ} \mathrm{C}$ for $72 \mathrm{~h}$, and crushed in an electric grinder (Di Grano MDR-302). The crushed material was stored in paper bags, free from light. The plant material was identified by Professor Doctor Rúbia Santos Fonseca and deposited in the herbarium of the State University of Montes Claros (MCMG), under voucher 6774 .

For the preparation of aqueous extracts (AE), $10 \mathrm{~g}$ of dehydrated leaves were crushed and added to $50 \mathrm{~mL}$ of sterile distilled water. The solution was then incubated in a water bath at $40{ }^{\circ} \mathrm{C}$ for $60 \mathrm{~min}$. Ethanol extracts (EE) were obtained by submerging $100 \mathrm{~g}$ of plant material in $1000 \mathrm{~mL}$ of PA ethanol (ethyl alcohol), in amber glass containers, and kept in a dark and dry place for seven days. The extracts were filtered through a funnel with gauze and cotton, and taken to a forced air circulation oven at $40{ }^{\circ} \mathrm{C}$, until constant weight was obtained (Morais-Costa et al., 2015, 2016).

\subsection{Evaluation of Condensed Tannin Content}


The CT content (adapted from Hiermann et al., 1986) was quantified in the AE and EE of the leaves after acid-catalyzed solvolysis with 37\% butanol/hydrochloric acid (95:5). For better use and saving of water resources, water recirculation equipment was adapted to the system, using an expanded polystyrene container (Styrofoam) and a submerged pump (model SB1000A). The absorbance of the solution was read on a spectrophotometer (Shimadzu UV-1800) at $540 \mathrm{~nm}$. Each sample was analyzed in triplicate and the results were expressed as the mean \pm standard deviations.

\subsection{Statistical Analysis}

The intensity index method was used to evaluate phenological events (Fournier, 1974), calculated as the mean intensity of a given phenophase among individuals (Bencke \& Morellato, 2002). The variation in CT levels in relation to months and seasonality was assessed by analysis of the generalized linear model (GLM) and chi-square test (Chisq). To compare the two extraction methods (ethyl alcohol and distilled water) the Student's $\mathrm{T}$ test was used. The analyzes were performed using R statistical software, version 3.5.1 (R Core Team, 2018). The phenological data of intensity of each phenophase were related to CT levels, with the total monthly precipitation and average temperature in the study period, through Spearman's correlation (Zar, 1996).

\section{Results}

\subsection{Phenological Behavior of Xylopia emarginata}

During the period evaluated, the highest percentage of mature leaves occurred in April 2018 (14.4\%) and the lowest in October of the same year (10.1\%). The highest percentages of leaf fall occurred in June $2018(7.2 \%)$, July $2018(6.8 \%)$ and January $2019(6.9 \%)$. For budding, the highest intensity rates were recorded from July (3.8\%) to September 2018 (3.6\%). It was observed that the production of X. emarginata leaves occurred throughout the study, with greater budding and leaf fall in the dry season. The reproduction of the species showed very low intensity in the year of study, with a low percentage of flowering $(0.67 \%)$ in the months of April and May/2018, and fruiting, from May to July/2018, in 17.0\% of the specimens monitored (Figure 2).

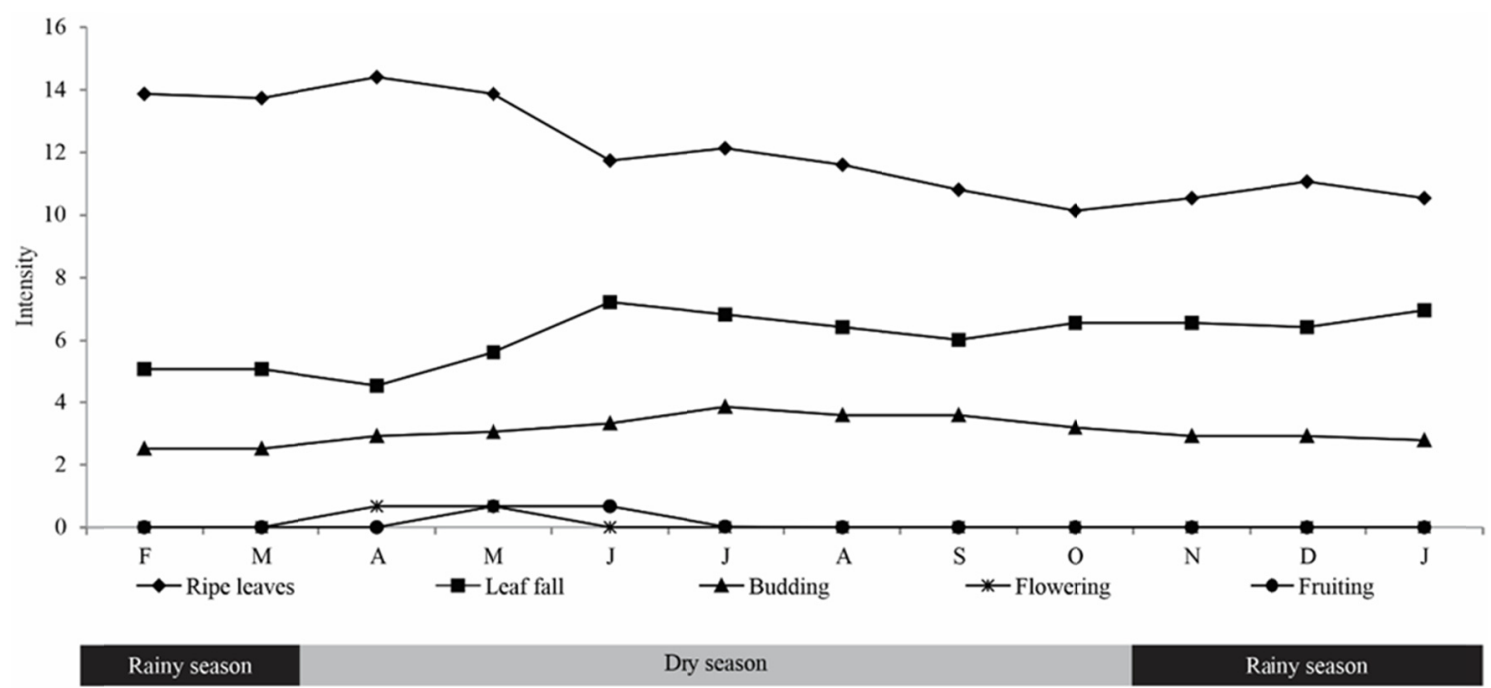

Figure 2. Intensity of vegetative and reproductive phenophases of specimens of Xylopia emarginata for one year (Feb / 2018 to Jan / 2019) at Vereda Almescla (EPA-Rio Pandeiros, Minas Gerais, Brazil)

\subsection{Condensed Tannin Content in X. emarginata Leaves}

During the experimental period, variations in the CT levels obtained from the leaves of $X$. emarginata were observed for the different extraction methods. In AE, higher concentrations were found in the months of May 2018 (6.6\%), June 2018 (6.6\%) and July 2018 (7.8\%). Similar results were obtained for EE in May 2018 (11.3\%), June 2018 (13.2\%) and July 2018 (11.9\%) (Figure 3). It was observed that the highest concentrations of CT were obtained in the dry season, being a period of drought, with lower temperatures and precipitation. 


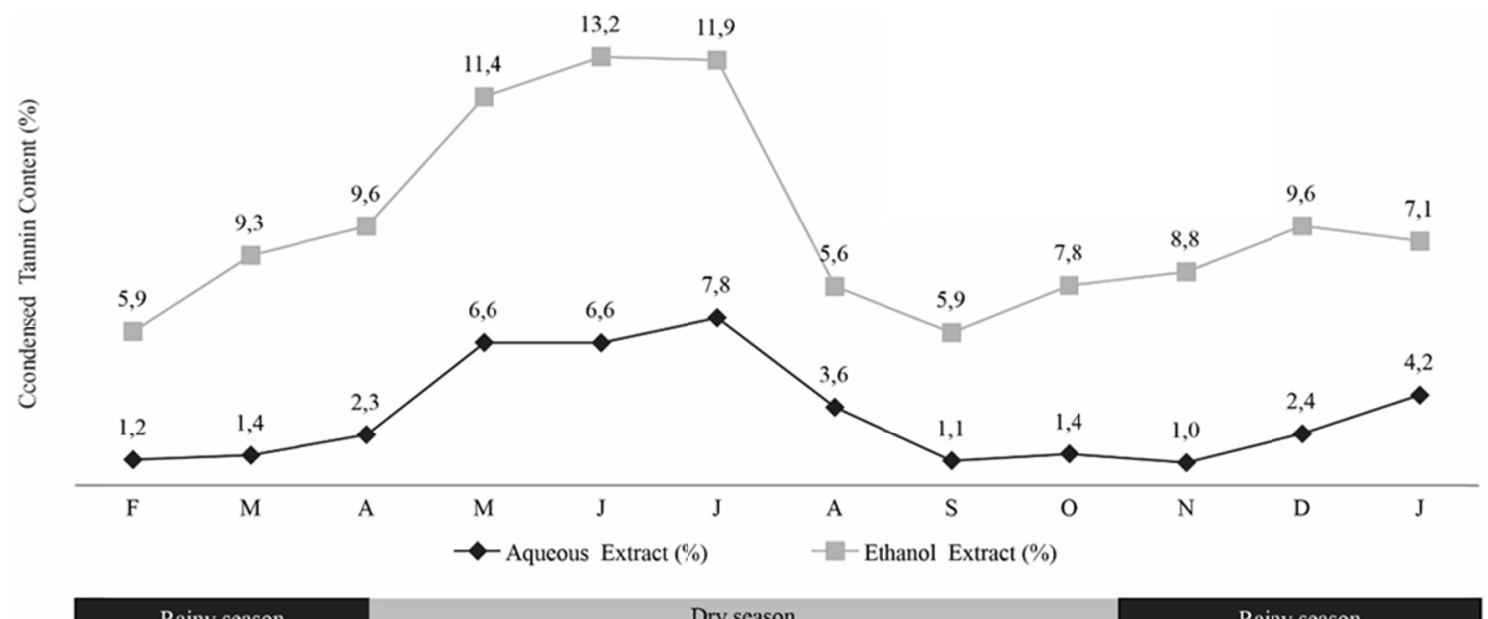

Figure 3. Percentages of condensed tannin contents of Xylopia emarginata leaves during one year of collection (February/2018 to January/2019) at Vereda Almescla (EPA-Rio Pandeiros, Minas Gerais, Brazil)

Throughout the season (rainy and dry), CT levels were quantified in the leaves of $X$. emarginata. No significant differences were found $(\mathrm{p}<0.05)$ between the monthly samples in the AE and EE, however, it was observed that the highest levels of $\mathrm{CT}$ occurred in the dry season. Comparing the two extraction methods (distilled water and ethyl alcohol), it was found that the AE extracted a smaller amount of CT from the leaves of X. emarginata. There was a significant difference $(\mathrm{p}<0.05)$ in the amount of CT levels between the two extraction methods.

An inverse and significant correlation was observed between budding and total precipitation $(r=-0.78 ; t=-3.92$; $\mathrm{p}<0.05)$ and also budding and average temperature $(\mathrm{r}=-0.61 ; \mathrm{t}=-2.44 ; \mathrm{p}<0.05)$. No correlation was found between the other vegetative phenological stages with climatic variables. Likewise, there was no significant correlation $(\mathrm{p}>0.05)$ between the levels of CTs in aqueous and ethanol extracts with vegetative phenology (Table 1).

Table 1. Correlation between intensity of vegetative and reproductive phenophases of Xylopia emarginata with climatic variables (total precipitation and average temperature) and levels of condensed tannins in aqueous (AE) and ethanolic (EE) extracts of leaves

\begin{tabular}{lllll}
\hline Phenophases & Precipitation $(\mathrm{mm})$ & Temperature $\left({ }^{\circ} \mathrm{C}\right)$ & AE Content $(\%)$ & EE Content $(\%)$ \\
\hline Budding & $-0.7788^{*}$ & $-0.6113^{*}$ & 0.3993 & 0.1166 \\
Leaf fall & -0.4331 & -0.0428 & 0.4077 & 0.1898 \\
Mature leaves & -0.0615 & -0.5614 & 0.2456 & 0.3965 \\
Flowering & -0.3239 & -0.1622 & 0.7319 & 0.3887 \\
Fruiting & $-0.7319^{*}$ & $-0.7332^{*}$ & $0.7457^{*}$ & $0.7457^{*}$ \\
\hline
\end{tabular}

Note. * Significant value $\mathrm{p}<0.05$.

An inverse and significant correlation was found between fruiting and total precipitation $(\mathrm{r}=-0.73 ; \mathrm{t}=-3.40 ; \mathrm{p}<$ $0.05)$ and also fruiting and average temperature $(\mathrm{r}=-0.73 ; \mathrm{t}=-3.96 ; \mathrm{p}<0.05)$. In contrast, there was a positive and significant correlation between fruiting and the total CT levels in the $\mathrm{AE}(\mathrm{r}=0.73 ; \mathrm{t}=3.39 ; \mathrm{p}<0.05)$ and with the total CT levels in the EE $(r=0.74 ; t=3.53 ; p<0.01)$ (Table 1). No correlation was found between the reproductive phenological stage of flowering with climatic variables, and with $\mathrm{CT}$ levels. There was an inverse and significant correlation between $\mathrm{CT}$ levels in $\mathrm{AE}$ and total precipitation $(\mathrm{mm})$ and average temperature $\left({ }^{\circ} \mathrm{C}\right)$, with no significant correlation in EE (Table 2). 
Table 2. Correlation between climatic variables (precipitation accumulation and average temperature) and content of condensed tannins in Aqueous Extract (AE) and Ethanol Extract (EE) of Xylopia emarginata leaves

\begin{tabular}{lll}
\hline Content of condensed tannins & Precipitation $(\mathrm{mm})$ & Temperature $\left({ }^{\circ} \mathrm{C}\right)$ \\
\hline Aqueous Extract & $-0.580^{*}$ & $-0.774^{*}$ \\
Ethanol Extract & -0.476 & -0.357 \\
\hline
\end{tabular}

Note. * Significant value $\mathrm{p}<0.05$.

\section{Discussion}

The variation in CT production in response to phenology and seasonality was verified in this study. The species $X$. emarginata showed a variation in the production of CT, according to seasonality, which caused an increase in the levels quantified in the dry season, mainly in the months of June and July, where the highest values of CT occurred in the AE and EE.

Previous studies on leaves of other Cerrado plant species, which used a similar extraction method with water as a solvent, also quantified CT during the dry season and reported a variation of 7.4\% (Casearia sylvestris), $6.4 \%$ (Paullinia sp.), 0.83\% (Caryocar brasiliense), 0.3\% (Ximenia americana), and 0.2\% (Piptadenia viridiflora) (Fonseca, 2014; Morais-Costa et al., 2015). Note that the species Casearia sylvestris and Paullinia sp. showed high levels of CT, even so, they were below the levels found for the species under study, X. emarginata, when collected and extracted in the dry period in the AE (highest value of $7.8 \%$ ).

The increase in CT levels during the dry season is consistent with the increase in other secondary metabolites during drought in other species. Water stress increased the amount of secondary metabolites found in the species Papaver somniferum (Szabó et al., 2003), Catharanthus roseus (Jaleel et al., 2007), and Annona lutescens (Castro-Moreno et al., 2013). Studies of other species, such as Murraya euchrestifolia (Wu et al., 1996) and Hydratis canadensis (Douglas et al., 2010), also pointed out the variation of secondary metabolites in leaf extracts according to seasonality. This confirms that seasonality with changes in temperature and precipitation may influence the production of secondary metabolites. What can be proven in this study, is that $X$. emarginata had its $\mathrm{CT}$ levels with variation according to seasonality with greater production in the dry period and greater quantification in $\mathrm{EE}(13.2 \%)$ in relation to $\mathrm{AE}(7.8 \%)$.

Plant species are dynamic organisms, whose accumulation of phenolic compounds varies with seasonality (Lima et al., 2009), depending on intrinsic (genetic) and extrinsic (environmental) factors (Frantianni et al., 2007) and varies with different seasons (Bussotti et al., 1998; Ma et al., 2003; Brooks \& Feeny, 2004). Thus, studies on the seasonal variation of phenolic compounds indicate that the climatic changes that occur during an annual cycle, notably those related to precipitation and temperature, influence the phenotypic changes in plants that alter their production pattern of phenolic compounds to suit situations of water stress (Ma et al., 2003; Brooks \& Feeny, 2004).

The vegetative phenological behavior of $X$. emarginata showed that the species is evergreen, with some variations in production and leaf fall throughout the year. However, only budding was influenced by climatic variables. The species showed low intensity of reproduction, which was restricted to dry months, but fruiting also responded to climatic factors. The manifestations of these phenological events responded negatively to the increase in precipitation and temperature. In addition, levels of CTs in the leaves of X. emarginata, both in the aqueous and in the ethanolic extracts, were higher in the period of fruiting of the species.

Budding during the dry season is an indication that the production of $X$. emarginata leaves is not limited by precipitation. This can be explained by the characteristics of the species, which occupies humid phytophysiognomies in the Cerrado (Mendonça et al., 2008). The study area is a Vereda, with vegetation associated with peat soils, sodden, with outflow of ground water (Nunes et al., 2015).

The vegetative phenological behavior of the species, despite varying between seasons, did not show abrupt variations, with budding, expansion, and leaf fall throughout the year. Low percentage values of intensity of reproductive phenophases were observed for $X$. emarginata in the present study. Flowering occurred during a short period, in April and May. Xylopia emarginata in the central region of the Amazon, also presented short flowering, (September and October), and only once in the period of two years of study, indicating that this species seems to have a supra-annual pattern and with irregular flowering (Webber \& Gottsberger, 1999).

The reproduction of $X$. emarginata was observed at the end of the rainy season, a fact that was also observed by Azevedo et al. (2014) in the riparian vegetation of the Pandeiros River, which comprises part of the area of this 
study. During two years of observation in the Amazon, Weber and Gottsberger (1999) did not notice fruiting for $X$. emarginata. Studies carried out by Ragusa-Netto (2008) in the Cerrado vegetation and in humid areas also noticed fruiting during the rainy season and for $X$. emarginata other fruiting peaks occurred in the middle of the dry season. For $X$. emarginata, further studies are needed to find out whether reproduction (flowering and fruiting) always occurs in the same season in subsequent years. Variation in flowering and fruiting periods related to precipitation are frequent in humid tropical forests (Bendix et al., 2006).

\section{Conclusion}

The study demonstrated that there was variation in the CT content of the $\mathrm{AE}$ and $\mathrm{EE}$ of the leaves of $X$. emarginata in response to phenology and climate (precipitation, temperature). The leaves of $X$. emarginata have the potential to extract CT in the dry period, and were higher in the period of fruiting of the species. The EE showed a higher quantification of $\mathrm{CT}$ contents in relation to the $\mathrm{AE}$.

The production of $X$. emarginata leaves in the Cerrado/Vereda occurred throughout the study period, registering a higher rate of budding and leaf fall during the dry season and less rainfall. The occurrence of the species in a humid habitat shows a behavior similar to that presented in humid Amazonian forests.

\section{References}

Abernethy, K., Bush, E. R., Forget, P.-M., Mendoza, I., \& Morellato, L. P. C. (2018). Current issues in tropical phenology: a synthesis. Biotropica, 50, 477-482. https://doi.org/10.1111/btp.12558

Alu'datt, M. H., Rababah, T., Alhamad, M. N., Almajwal, A., Gammoh, S., Ereifej, K., ... Alli, L. (2017). A review of phenolic compounds in oil-bearing plants: distribution, identification and occurrence of phenolic compounds. Food Chem, 218, 99-106. https://doi.org/10.1016/j.foodchem.2016.09.057

Alvares, C. A., Stape, J. L., Sentelhas, P. C., Gonçalves, J. L. M., \& Sparovek, G. (2013). Köppen's climate classification map for Brazil. Meteorol Z, 22, 711-728. https://doi.org/10.1127/0941-2948/2013/0507

Andrew, D. R., Trevor, F. K., Mirco, M., Youngryel, R., Oliver, S., \& Michael, T. (2013). Climate change, phenology, and phenological control of vegetation feedbacks to the climate system. Agric For Meteorol, 169, 156-73. https://doi.org/10.1016/j.agrformet.2012.09.012

Azevedo, I. F. P., Nunes, Y. R. F., Ávila, M. A., Silva, D. L., Fernandes, G. W., \& Veloso, R. B. (2014). Phenology of riparian tree species in a transitional region in southeastern Brazil. Braz J Bot, 37, 47-59. https://doi.org/10.1007/s40415-014-0046-5

Bencke, C. S., \& Morellato, L. P. C. (2002). Comparação de dois métodos de avaliação da fenologia de plantas, sua interpretação e representação. Braz J Bot, 25, 269-275. https://doi.org/10.1590/S0100-84042002000300003

Bendix, J., Homeier, J., Cueva Ortiz, E., Emck, P., Breckle, S.-W., Richter, M., \& Beck, E. (2006). Seasonality of weather and tree phenology in a tropical evergreen mountain rain forest. Int $J$ Biometeorol, 50, 370-384. https://doi.org/10.1007/s00484-006-0029-8

Brooks, J. S., \& Feeny, P. (2004). Seasonal variation in Daucus carota leaf-surface and leaf-tissue chemical profiles. Biochem Syst Ecol, 32, 769-782. https://doi.org/10.1016/j.bse.2004.01.004

Bussotti, F., Gravano, E., Grossoni, P., \& Tani, C. (1998). Occurrence of tannins in leaves of beech trees (Fagus sylvatica) along an ecological gradient, detected by histochemical and ultrastructural analyses. New Phytol, 138, 469-479. https://doi.org/10.1046/j.1469-8137.1998.00121.x

Castro-Moreno, M., Tinoco-Ojangure'n, C., Cruz-Ortega, M. R., \& Gonza'lez-Esquinca, A. R. (2013). Influence of seasonal variation on the phenology and liriodenine content of Annona lutescens (Annonaceae). $J$ Plant Res, 126, 529-537. https://doi.org/10.1007/s10265-013-0550-x

Chuine, I., \& Régnière, J. (2017). Process-based models of phenology for plants and animals. Annu Rev Ecol Evol Syst, 48, 159-182. https://doi.org/10.1146/annurev-ecolsys-110316-022706

Cruz, J. P., Vasconcelos, V. O., Medeiros, P. C., Figueiredo, J. C., Nunes, Y. R. F., Duarte, E. R., \& Venuto, A. P. (2021). Acaricide potential of Xylopia emarginata Mart. leaf extract against Rhipicephalus microplus larvae. Agrarian Sciences Journal, 13, 1-5. https://doi.org/10.35699/2447-6218.2021.34636

Djerrad, Z., Kadik, L., \& Djouahri, A. (2015). Chemical variability and antioxidant activitiesamong Pinus halepensis Mill. essential oils provenances, depending on geographicvariation and environmental conditions. Ind Crops Prod, 74, 440-449. https://doi.org/10.1016/j.indcrop.2015.05.049 
Douglas, J., Follett, J. M., Parmener, G. A., Sansom, C. E., Perry, N. B., \& Littler, R. A. (2010). Seasonal variation of biomass and bioactive alkaloid content of goldenseal, Hydrastis canadensis. Fitoterapia, 81, 925-928. https://doi.org/10.1016/j.fitote.2010.06.006

Fischer, D. C. H., Gualda, N. C. A., Bachiega, D., Carvalho, C. S., Lupo, F. N., Bonotto, S. V., ... Hrihorowitsch R. P. M. (2004). In vitro screening for antiplasmodial activity of isoquinoline alkaloids from Brazilian plant species. Acta Tropica, 92, 261-266. https://doi.org/10.1016/j.actatropica.2004.08.009

Fonseca, L. D., Viera, T. M., Lázaro, M. L. F. S., Ferreira, A. V. P., Bastos, G. A., Morais-Costa, F. M., ... Duarte, E. R. (2014). Eficácia in vitro de extratos aquosos de plantas no controle de nematódeos gastrintestinais de bovinos. Acta Sci Vet, 42, 1-8.

Fournier, L. A. (1974). Un metodo cuantitativo para la mediciónde caracteristicas fenológicas en arboles. Turrialba, 24, 422-423.

Fratianni, F., Tucci, M., Palma, M., Pepe, R., \& Nazzaro, F. (2007). Polyphenolic composition in different parts of some cultivars of globe artichoke (Cynara cardunculus L. var scolymus (L.) Fiori). Food Chem, 104, 1282-1286. https://doi.org/10.1016/j.foodchem.2007.01.044

Getachew, G. (1999). Tannins in tropical multipurpose tree species: Localization and quantification of tannins using histochemical approaches and the effect of tannins on in vitro rumen fermentation. Verlag Ulrich $\mathrm{E}$. Grauer, Stuttgart.

Hiermann, A., Kartnig, T. H., \& Azzam, S. (1986). Ein beitrag zur quantitativen bestimmung der procyanidine in crataegus. Sci Pharm, 54, 331-337.

Jaleel, C. A., Manivannan, P., Kishorekumar, A., Sankar, N., Gopi, R., Somasundarm, R., \& Panneerselvam, R. (2007). Alterations in osmoregulation, antioxidant enzymes and indole alkaloid levels in Catharanthus roseus exposed to water deficit. Colloids and Surf B Biointerfaces, 59, 150-157. https://doi.org/10.1016/ j.colsurfb.2007.05.001

Lieth, H. (1974). Phenology and seasonality modeling. Springer-Verlag, Berlin. https://doi.org/10.1007/ 978-3-642-51863-8

Lima, S. S., Tavares, E. S., Moreira, D. L., Leitão, G. G., \& Esquibel, M. A. (2009). Anatomia de folha e caule e quantificação espectrofotométrica de fenóis totais e taninos da erva-de-bicho (Polygonum acre Kunth var. aquatile Meisn.). Rev. Brasil. Bot., 32, 339-348. https://doi.org/10.1590/S0100-84042009000200013

Lorenzi, H. (1992). Árvores brasileiras: Manual de identificação e cultivo de plantas arbóreas nativas do Brasil. Plantarum, Nova Odessa.

Ma, M., Hong, C., An, S., \& Li, B. (2003). Seasonal, spatial, and interspecific variation in quercetin in Apocynum venetum and Poacynum hendersonii, Chinese traditional herbal teas. $J$ Agric Food Chem, 51, 2390-2393. https://doi.org/10.1021/jf021055i

Macedo, M., \& Ferreira, A. R. (2004). Plantas medicinais usadas para tratamentos dermatológicos, em comunidades da Bacia do Alto Paraguai, Mato Grosso. Rev Bras Farmacogn, 14, 40-44. https://doi.org/ $10.1590 / \mathrm{S} 0102-695 \mathrm{X} 2004000300016$

Mendonça, R. C., Felfili, J. M., Walter, B. M. T., Silva-Júnior, M. C., Rezende, A. V., Filgueiras, T. S., ... Fagg, C. W. (2008). Flora vascular do bioma cerrado: Checklist com 12356 espécies. In S. M. Sano, S. P. Almeida, \& J. F. Ribeiro (Eds.), Cerrado: Ecologia e flora (Vol. 2). Embrapa Cerrados, Brasília.

Mesquita, M. L., Grelier, P., Mambu, L., De Paula, J. E., \& Espinola, L. S. (2007). In vitro antiplasmodial activity of Brazilian cerrado plants used as traditional remedies. $J$ Ethnopharmacol, 110, 165-170. https://doi.org/10.1016/j.jep.2006.09.015

Monteiro, J. M., Albuquerque, U. P., \& Araújo, E. L. (2005). Taninos: Uma abordagem química à ecologia. Quim Nova, 28, 892-896. https://doi.org/10.1590/S0100-40422005000500029

Morais-Costa, F., Bastos, G. A., Soares, A. C. M., Costa, E. G. L., Vasconcelos, V. O., Oliveira, N. J. F., ... Lima, W. S. (2016). In vitro and in vivo action of Piptadenia viridiflora (Kunth) Benth against Haemonchus contortus in sheep. Vet Parasitol, 223, 43-49. https://doi.org/10.1016/j.vetpar.2016.04.002

Morais-Costa, F., Soares, A. C. M., Bastos, G. A., Nunes, Y. R. F., Geraseev, L. C., Braga, F. C., .. Duarte, E. R. (2015). Plants of the Cerrado naturally selected by grazing sheep may have potential for inhibiting development of Haemonchus contortus larva. Trop Anim Health Prod, 47, 1321-1328. https://doi.org/ $10.1007 / \mathrm{s} 11250-015-0866-8$ 
Moreira, I. C., Lago, J. H. G., \& Roque, N. F. (2003). Alkaloid, flavonoids and terpenoids from leaves and fruits of Xylopia emarginata (Annonaceae). Biochem Syst Ecol, 31, 535-537. https://doi.org/10.1016/S0305-1978 (02)00180-1

Moreira, I. C., Roque, N. F., \& Lago, G. (2006). Diterpene adducts from branches of Xylopia emarginata. Biochem Syst Ecol, 34, 833-837. https://doi.org/10.1016/j.bse.2006.07.001

Moreira, I. C., Roque, N. F., Contini, K., \& Lago, J. H. G. (2007). Sesquiterpenos e hidrocarbonetos dos frutos de Xylopia emarginata (Annonaceae). Rev Bras Farmacogn, 17, 55-58. https://doi.org/10.1590/S0102-695 X2007000100012

Nascimento, A., Ribeiro, E. A. N., Oliveira, J. M., Medeiros, F. A., Silva, M. S., \& Medeiros, I. A. (2006). Cardiovascular effects induced by the hydroalcoholic extract of the stem Xylopia cayennensis in rats. Rev Bras Farmacogn, 16, 17-21. https://doi.org/10.1590/S0102-695X2006000100005

Nunes, Y. R. F., Bahia, T. O., Avila, M. A., Veloso, M. D. M., \& Santos, R. M. (2015). Florística e fitossociologia das comunidades arbóreas de veredas: Um estudo de caso no norte de Minas Gerais, Brasil. In P. V. Eisenlohr, J. M. Felfile, M. M. R. F. Melo, L. A. Andrade, \& J. A. A. M. Meira-Neto (Eds.), Fitossociologia no Brasil: Métodos e estudos de casos (pp. 264-287). Editora UFV, Viçosa.

Nunes, Y. R. F., Fagundes, M., Santos, R. M., Domingues, E. B. S., Almeida, H. S., \& Gonzaga, A. P. D. (2005). Atividades fenológicas em Guazuma ulmifolia Lam. (Malvaceae) em uma Floresta Estacional Decidual no norte de Minas Gerais. Lundiana, 6, 99-105.

Pirbalouti AG, Firoznezha M, Craker L, Akbarzadeh M (2013) Essential oil compositions, antibacterial and antioxidant activities of various populations of Artemisia chamaemelifolia at two phenological stages. Rev Bras Farmacogn, 23, 861-869. https://doi.org/10.1590/S0102-695X2013000600002

Pretti, I. R., Luz, A. C., Jamal, C. M., \& Batitucci, C. P. (2018). Variation of biochemical and antioxidant activity with respect to the phenological stage of Tithonia diversifolia Hemsl. (Asteraceae) populations. Ind Crops Prod, 121, 241-249. https://doi.org/10.1016/j.indcrop.2018.04.080

Ragusa-Netto, J. (2008). Toco toucan feeding ecology and local abundance in a habitat mosaic in the Brazilian Cerrado. Ornitologia Neotropical, 19, 345-359.

Rocha, W. S., Lopes, R. M., Silva, D. B., Vieira, R. F., Silva, J. P., \& Agostini-Costa, T. S. (2011). Compostos fenólicos totais e taninos condensados em frutas nativas do Cerrado. Rev Bras Frutic, 33, 1215-1221. https://doi.org/10.1590/S0100-29452011000400021

Sant'ana, P. J., \& Assad, A. L. (2002). O contexto brasileiro para a bioprospecção. Biotecnologia Ciência e Desenvolvimento, 29, 32-37.

Schweitzer, J. Á., Madritch, M. D., Bailey, J. K., Leroy, C. J., Fischer, D. G., Rehill, B. J., ... Whitham, T. G. (2008). From genes to ecosystems: The genetic basis of condensed tannins and their role in nutrient regulation in a Populus model system. Ecosystems, 11, 1005-1020. https://doi.org/10.1007/ s10021-008-9173-9

Silva, L. E., Reis, R. A., Moura, E. A., Amaral, W., \& Sousa-Junior, P. T. (2015). Plantas do gênero Xylopia: composição Química e potencial farmacológico. Rev Bras Plantas Med, 17, 814-826. https://doi.org/ 10.1590/1983-084X/14_076

Simón, B. F., Cadahia, E., Conde, E., \& Garcí-Vallejo, M. C. (1999). Evolution of phenolic compounds of spanish oak wood during natural seasoning. First results. J Agric Food Chem, 47, 1687-1694. https://doi.org/10.1021/jf9805855

Sousa, F. D. M., Grossi, S. M., Monteiro, G. C., Demarque, D. P., \& Espindola, L. S. (2020). Dereplication and isolation of larvicidal compounds from Annonaceae species against Aedes aegypti. Rev Bras Farmacogn, 30, 123-126. https://doi.org/10.1007/s43450-020-00018-4

Szabó, B. L. A., \& Kõszegi, T. B. L. (2003). HPTLC and HPLC determination of alkaloids in poppies subjected to stress. JPC-J Planar Chromat ,16, 293-297. https://doi.org/10.1556/jpc.16.2003.4.9

Webber, A. C., \& Gottsberger, C. A. (1999). Phenological patterns of six Xylopia (Annonaceae) species in Central Amazonia. Phyton, 39, 293-301.

Wu, T. S., Wang, M. L., \& Wu, P. L. (1996). Seasonal variations of carbazole alkaloids in Murraya euchrestifolia. Phytochemistry, 43, 785-789. https://doi.org/10.1016/0031-9422(96)00361-5 
Zar, J. H. (1996). Biostatistical analysis (3th ed.). Prentice-Hall, New Jersey.

Zucker, W. V. (1983). Tannins: Does structure determine function? An ecological perspective. Am Nat, 121, 335-365.

\section{Appendix A}

\section{Graphical abstract}

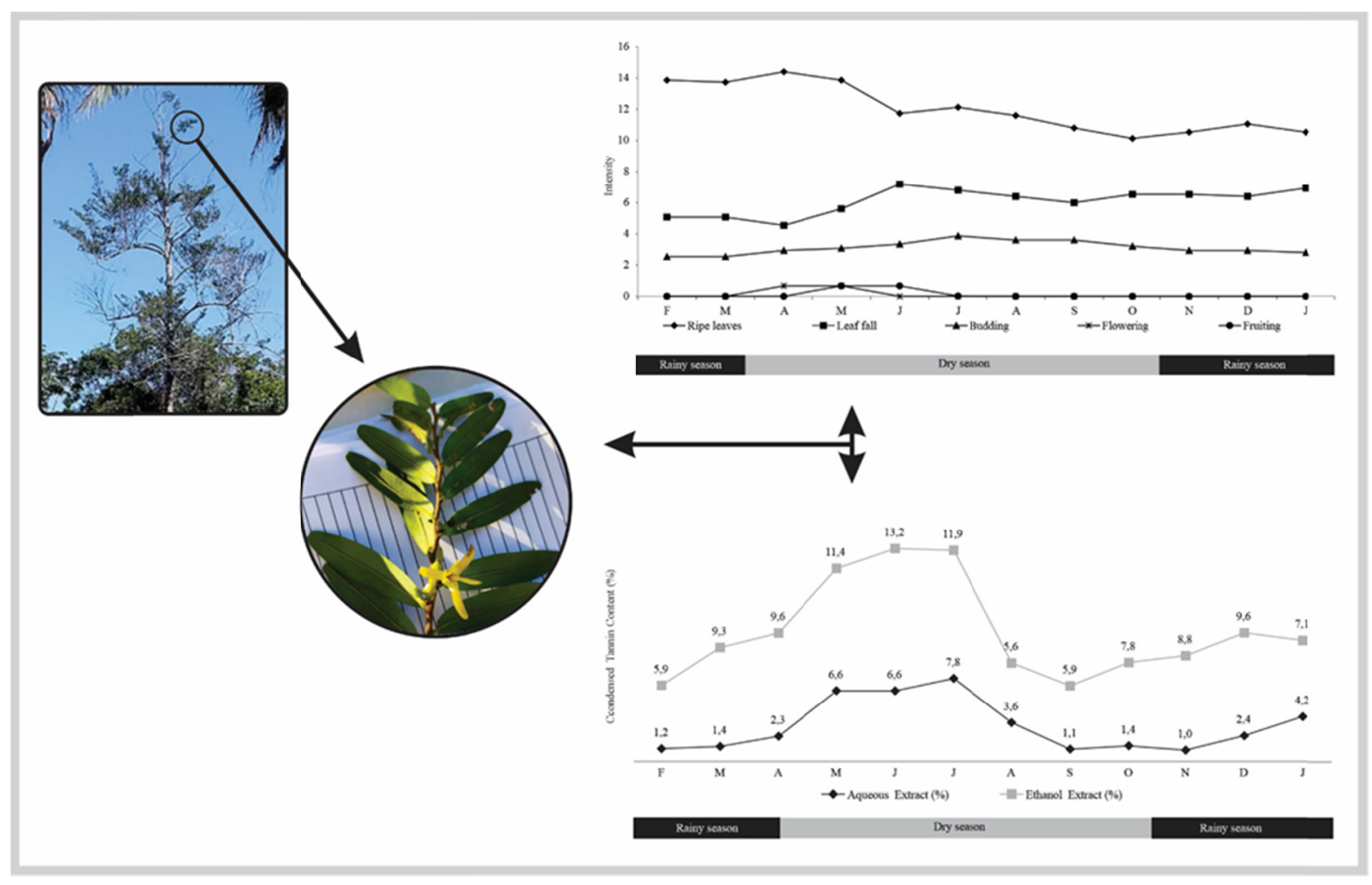

\section{Copyrights}

Copyright for this article is retained by the author(s), with first publication rights granted to the journal.

This is an open-access article distributed under the terms and conditions of the Creative Commons Attribution license (http://creativecommons.org/licenses/by/4.0/). 